\title{
ENTRE CULTURA, SOLIDARIEDADE INTERNACIONAL E “MUNDO NEGRO”: A NEGOCIAÇÃO DE SENTIDOS NA PréSENCE Africaine (1955-1956)
}

Raissa Brescia dos Reis (DD $\square$ Universidade Federal do Rio de Janeiro

partir da década de 1940, processos de independência pulularam
na Ásia e, posteriormente, na África. Com a emancipação política,
países não industrializados e sem poderio bélico organizaram-se para representar seus interesses e utilizar sua nova posição para barganhar direitos e um lugar de enunciação reconhecido. Nesse cenário, o colonialismo surgiu como a configuração política a ser combatida e superada por um novo conjunto de atores internacionais que se organizavam. Ao mesmo tempo, a tendência que ficaria conhecida como "terceiro-mundista” emergia.

A efervescência de algumas das primeiras movimentações internacionais realizadas em nome dos novos países foi marcada, por excelência, pela Conferência Afro-Asiática, mais conhecida como Conferência de Bandung, realizada em 1955, na cidade indonésia de mesmo nome, sob a premissa da "autodeterminação”. Naquela ocasião, a afirmação do lugar estratégico ocupado pelos países ex-colonizados ou sob dominação econômica na formação de uma nova ordem internacional foi um dos principais fomentadores do que se convencionou chamar no período de “espírito de Bandung”. ${ }^{1}$ Apesar dos termos das relações internacionais não terem partido do interesse em dar armas aos países que

1 Christopher Lee, Making a World after Empire: the Bandung moment and its political afterlives, Athens: Ohio University Press, 2010, p. 15. 
se formavam, ou de ampliar o número de protagonistas no jogo político mundial, a agência de lideranças, instituições e atores sociais coletivos e individuais promoveu apropriações e mudanças significativas em seu interior durante as décadas de 1950 e 1960.

Para os objetivos deste artigo, é em tal contexto global que se procurou situar as publicações da revista cultural francesa e senegalesa, Présence Africaine. ${ }^{2}$ A hipótese aqui introduzida é a de que a revista procurou se posicionar, partindo do mundo intelectual, como interventora na imaginação e no fomento de soluções políticas e culturais para inserir novos participantes, principalmente africanos, inclusive estatais, no concerto internacional, por meio de bandeiras de solidariedade internacional/racial entre perspectivas locais e globais. Assim, propõe-se - marcadamente a partir da análise de debates, comunicações e mensagens retiradas das atas do Primeiro Congresso de Escritores e Artistas Negros, ${ }^{3}$ publicadas no número especial 8-9-10, de 1956, da Présence Africaine - investigar como a revista procurou fortalecer sua posição como um dos nós de uma rede intelectual transcontinental. Enquanto instituição de projeção cultural, a publicação se apropriou de novas linguagens e possibilidades políticas disponíveis e legitimadas no pós-Segunda Guerra Mundial, conciliando-as, não sem dificuldades, com discursos internacionalistas de movimentos anteriores à Segunda Guerra Mundial, como a Négritude e o pan-africanismo. ${ }^{4}$

2 Esse periódico foi fundado por Alioune Diop em 1947, em Paris, congregando, em um só veículo e em um projeto de “mundo negro”, África e Diásporas, que mais tarde seriam unidas também a outras partes do planeta por meio da ideia de Terceiro Mundo. A Présence Africaine tornou-se também uma editora a partir de 1949, foi considerada como revista da Société Africaine de Culture, criada em 1956, e permanece em exercício enquanto publicação e editora até os dias de hoje.

3 Congresso realizado em setembro de 1956, em Paris, na Sorbonne, com a promoção e organização da Présence Africaine, do qual participaram ativamente intelectuais africanos e americanos e ao qual compareceram várias figuras intelectuais francesas, além de estudantes africanos e europeus.

4 Este artigo propõe a revisão de perspectivas como a de Joseph Hongoh, de que Bandung levou a uma adesão irreversível ao paradigma do Estado-nação e ao abandono, por parte dos atores políticos africanos, de outras perspectivas internacionalistas. Vê-se, ao contrário, como a participação e apropriação de práticas do campo das relações internacionais e do discurso da solidariedade do dito Terceiro Mundo implicaram não só a permanência e relevância de atores não nacionais no campo da política 
A revista, criada por Alioune Diop em 1947, sob os auspícios de conhecidos intelectuais africanos, americanos e europeus, como Léopold Sédar Senghor, Richard Wright, Aimé Césaire e André Gide, esforçou-se para se apresentar como divulgadora e construtora dos elementos de uma política transnacional do Terceiro Mundo durante a segunda metade da década de 1950 e mesmo após 1960. Para isso, no entanto, ela teve que lidar com a emergência do Estado-nação como propagador privilegiado de enunciados e de regras no jogo de forças mundial e regional e com a eventual contradição entre essa configuração e o paradigma racial e/ou continental herdado de movimentos como a Négritude e o pan-africanismo. ${ }^{5}$

internacional africana, como envolveram engajamento de diversos atores na criação de pontes entre diferentes bandeiras internacionalistas, aqui destacados os intelectuais. Ver Joseph Hongoh, "The Asian-African Conference (Bandung) and Pan-africanism: The Challenge of Reconciling Continental Solidarity with National Sovereignty”, Australian Journal of International Affairs, v. 70, n. 4 (2016), pp. 374-390.

5 Muitos são os trabalhos que exploram as relações entre a Présence Africaine, a Négritude e o pan-africanismo, mesmo nos primeiros trabalhos feitos sobre o movimento negritudiano, como comprova Lilyan Kesteloot, Les écrivains noirs de langue française: naissance d'une littérature, Bruxelles: Université Libre de Bruxelles; Institut de Sociologie, 1963. Algumas referências importantes para este trabalho são: a obra coletiva organizada por Valentin-Yves Mudimbe (ed.), The Surrepitious Speech, Chicago; London: The University of Chicago Press, 1992; o dossiê "Présence Africaine. Les conditions noires: une généalogie des discours”, Gradhiva, n. 10 (2009); e o artigo de Salah D. Hassan, “The Cultural Politics of the Early 'Présence Africaine, 1947-55”,, Research in African Literatures, v. 30, n. 2 (1999), pp. 194-221. Cabe sinalizar ainda a crescente produção nacional sobre a Négritude com as dissertações de mestrado de Gustavo de Andrade Durão, "A construção da Negritude: a formação da identidade do intelectual através da experiência de Léopold Sédar Senghor (1920-1945)”, Dissertação (Mestrado em História), Universidade de Campinas, Campinas, 2011, e de Raissa Brescia dos Reis, "Négritude em dois tempos: emergência e instituição de um movimento (1931-1956)”, Dissertação (Mestrado em História), Universidade Federal de Minas Gerais, Belo Horizonte 2014; bem como sobre o pan-africanismo, como aponta a tese de Guillermo Antonio Navarro Alvarado, “África deve se unir? A formação da teorética da unidade e a imaginação da África nos marcos epistêmicos pan-negristas e pan-africanos (séculos XVIII-XX)”, Tese (Doutorado em Estudos Étnicos e Africanos), Universidade Federal da Bahia, Salvador, 2018. Mais especificamente pensando a Présence Africaine, cito Raissa Brescia dos Reis “África imaginada: história intelectual, pan-africanismo, nação e unidade africana na Présence Africaine (1947-1966)”, Tese (Doutorado em História), Universidade Federal de Minas Gerais, Belo Horizonte, 2018, e o recente artigo de Muryatan S. Barbosa, "O debate pan-africanista na revista Présence Africaine (1956-1963)”, História, v. 38 (2019), pp. 1-21. A abordagem aqui apresentada é fruto de uma trajetória de pesquisa inserida no crescimento do tema, nos últimos anos, no cenário brasileiro e procura se diferenciar de 
Não é por acaso, portanto, que em muitos dos debates que se analisa aqui tenha ocorrido uma polarização entre pressupostos nacionais e raciais para pensar identidades, culturas e possíveis intervenções, ou projetar políticas culturais, agendas de engajamento e redes de solidariedade. ${ }^{6}$

trabalhos mais amplos sobre a Négritude ou sobre o pan-africanismo por seu foco na história da revista e no contexto político e social de disputas que permeia, mas também ultrapassa, o campo intelectual e das ideias. O destaque deste artigo vai para a análise da revista como criadora e nó de uma rede internacional de ideias e repertórios de engajamento com referência também ao terceiro-mundismo.

6 As definições de Négritude e de pan-africanismo não são objeto nem objetivo deste artigo, que procura discutir a revista Présence Africaine e a forma como ela mobiliza esses dois movimentos enquanto tradições de internacionalismo negro e os conjuga com o terceiro-mundismo. Cabe esclarecer, porém, que esses dois termos são aqui usados para se referir a dois movimentos políticos e intelectuais que considero como distintos, com histórias diferentes, embora interseccionadas pela mobilização de conceitos como "raça negra", bem como pelo esforço de crítica a teorias europeias e racistas de hierarquização racial. O pan-africanismo, anterior ao movimento da Négritude, surge em um contexto mais ou menos difuso, em meados do século XIX, entre intelectuais e políticos negros caribenhos e estadunidenses, como Alexander Crummell, Edward Blyden e, mais tarde, William E. B. Dubois, marcado por um registro do discurso político ou acadêmico. Este ganha força na primeira metade do século XX, em sua versão ligada aos congressos internacionais e a um forte teor de engajamento internacional, inclusive em questões que permeiam o futuro do colonialismo europeu na África. Já a Négritude nomeia um movimento cujos primeiros expoentes são geralmente ligados ao grupo de estudantes universitários antilhanos e africanos que habitava Paris nas décadas de 1920 e 1930, ambiente no qual o próprio vocábulo foi criado. Entre os principais autores normalmente ligados a esse movimento de apropriação e valorização de uma identidade negra, inclusive diretamente influenciado pela tradição de pensamento racial pan-africanista estadunidense, mas também pela bibliografia etnológica de Léo Frobenius e de outros autores europeus, estavam Léopold Sédar Senghor, Aimé Césaire e Léon Gontran Damas, com sua produção poética. Além das diferenças contextuais evidentes, dadas pelo pertencimento dos pensadores envolvidos em cada um dos movimentos a grupos sociais, a origens geográficas e a arcabouços teóricos distintos, muitos analistas destacam o fator linguístico como importante para entender as clivagens entre as abordagens, sendo os escritos do pan-africanismo até meados do século XX geralmente produzidos em inglês, e os da Négritude, como o nome denota, em francês. Central aqui é entender que a Présence Africaine possuía ligações políticas, institucionais e teóricas importantes com ambos os grupos e movimentos desde seu primeiro número, sendo marcada tanto pela presença e pelo patronato dos poetas da Négritude quanto por referências aos intelectuais e aos discursos do pan-africanismo, como a tradução de Blyden comprova. Para um aprofundamento nessas importantes tradições teóricas e intelectuais, que não podem ser encerradas em uma nota, consultar a bibliografia citada na nota 5 deste artigo. Para discussões em torno de diferenciar ou não a Négritude e o pan-africanismo, ver também Kwame Anthony Appiah, Na casa de meu pai: a África na filosofia da cultura, Rio de Janeiro: Contraponto, 1997 e Abogo M'Bah, "Panafricanismo clásico: identidad y reconocimiento”, Nsibidi, n. 1 (2004), pp. 1-22. 
Por um lado, a presença dessas discussões no periódico, na segunda metade da década de 1950, representou uma viragem em sua história, ligando-se a mudanças que começaram por sua organização institucional e política editorial. ${ }^{7}$ Entre os anos de 1949 e 1955, a publicação passou por problemas financeiros e por uma reconfiguração ligada à saída de Diop do cargo de conselheiro da República. ${ }^{8}$ A dedicação exclusiva do intelectual nascido em Saint-Louis do Senegal à Présence Africaine, desde 1949, foi um dos elementos que culminaram em um relançamento dos números da revista em 1955, inaugurados por uma proposta editorial que chamava atenção dos seus leitores para sua vocação "antirracista e anticolonialista”:

Existe uma outra condição sobre a qual permitirão que nós insistamos: é a aquela do posicionamento da revista. Todos os artigos serão publicados sob reserva de que sua postura seja adequada, que sejam relacionados à África, que não traiam nem nossa vontade antirracista e anticolonialista, nem a solidariedade dos povos colonizados. Cristãos e muçulmanos, progressistas e nacionalistas, pagãos ou ateus devem conseguir evitar de se prender às particularidades ideológicas ou confessionais dos outros. Cada colaborador, guardando sua personalidade, deve lembrar que o que nos separa é bem menor do que o que nos ameaça ou nos falta. ${ }^{9}$

Por outro lado, mesmo perpassada por essas questões, que se poderia pensar como eminentemente políticas, a Présence Africaine -

7 Hassan, “The Cultural Politics of the Early 'Présence Africaine’”, pp. 194-197.

8 O Conseil de la République substituiu, durante a Quarta República, o Sénat, da Terceira República (1870-1940). De 1946 a 1948, os seus membros eram chamados de "conselheiros da República”, mas a partir de 1948 passaram a ser identificados novamente como "senadores". Alioune Diop figurava como terceiro na lista apresentada pelo partido socialista da Seção Francesa da Internacional Operária (SFIO) do Senegal, em 1946. Como a legenda conseguiu no pleito três lugares no conselho, Diop é eleito ao cargo e passa a fazer parte das Comissões da França de Além-Mar e da Imprensa. Ver “Diop, Alioune”, Sénat 飞.

9 "Liminaire”, Présence Africaine, n. 1-2 (1955), p. 5. As traduções das citações diretas são da autora. 
anunciada como livre de "obediência a qualquer ideologia filosófica ou política”, no texto inaugural de Alioune Diop, publicado no número 1, de 1947, e como símbolo da recusa a se “deixar domesticar” por qualquer partido ou escola filosófica, em 1949 - permanece afirmando seu engajamento estritamente “cultural”, mesmo após a declaração de interesses anticoloniais e antirracistas, em $1955 .{ }^{10}$ Além disso, com a recontagem dos números, a revista passa também a ostentar o subtítulo "revista cultural do mundo negro”, sublinhando a importância de paradigmas pan-africanistas e negritudianos. ${ }^{11}$

Assim, a investigação dos usos e das negociações em meio à Présence Africaine, no interior de sentidos e práticas próprios ao internacionalismo de meados do século XX, e de seus jogos de força tensionados pela Guerra Fria, levanta também o questionamento sobre as potencialidades e os limites da posição (não) política da revista. Quais diálogos foram criados entre um veículo de informação produzido por intelectuais, principalmente oeste-africanos, e endereçado a seus congêneres, principalmente na própria África, na Europa e na diáspora, e práticas políticas internacionalistas, voltadas para coletividades institucionais, raciais ou até estatais? Em quais circunstâncias a Présence Africaine pode ser entendida como uma fonte válida para se trabalhar as tensões que atuavam sobre a formação de novos repertórios políticos e espaços de negociação internacionais no período investigado?

O que se propõe a seguir é uma análise das fontes anunciadas a partir de tais problemas, sempre pensando no contexto em que elas foram produzidas e nelas mesmas como intervenções diretas.

10 A Présence Africaine é anunciada como livre de "obediência a qualquer ideologia filosófica ou política”, em Alioune Diop, “Niam n'goura ou les raisons d’être de la Présence Africaine”, Présence Africaine, n. 1 (1947), p. 7; como símbolo da recusa a se "deixar domesticar” por qualquer partido ou escola filosófica, em Alioune Diop, "Malentendus”, Présence Africaine, n. 6 (1949), p. 3; e como estritamente “cultural”, sem jamais se reduzir a um partido político, em "Liminaire”, Présence Africaine, n. 1-2 (1955), p. 1.

11 Subtítulo que passa a acompanhar o nome da revista na folha de rosto da publicação a partir do número 1 da Nova série (Nouvelle série), lançada em 1955. 


\section{O argumento do "equilíbrio mundial” aplicado em escala regional}

As mudanças institucionais no interior da Présence Africaine na década de 1950 dialogaram, em uma esfera mais larga, com as transformações que abrangiam boa parte da intelectualidade oeste-africana e indicavam a adoção de posicionamentos mais polarizados. A dificuldade de implantar a igualdade de direitos políticos e a paridade de representação para todos os membros da União Francesa nas instituições da Quarta República minavam o otimismo que marcou a entrada desses atores no jogo político oficial durante as assembleias constituintes de 1946, de que participaram deputados como Aimé Césaire, Léopold Sédar Senghor, Lamine Senghor e Félix Houphouët-Boigny. ${ }^{12}$

A ineficácia do texto constitucional de 1946 em criar uma relação mais igualitária entre a França e suas antigas colônias foi uma das razões de seu curto tempo de aplicação. Este terminaria oficialmente em 1958, com a aprovação de uma nova Constituição e o início da Quinta República, mas foi colocado em questão em vários momentos ao longo da década de 1950, muitas vezes pelas vozes dos intelectuais e representantes políticos da África do Oeste, que por sua vez contribuíram com ou frequentaram o mundo que circundava a Présence Africaine. As mudanças vistas na política editorial, nas escolhas temáticas e nos espaços de performance promovidos pela revista para o intelectual negro e oeste-africano entre 1949 e 1955 devem ser entendidas, portanto, em um processo no qual vários setores das elites do além-mar questionavam os andamentos da União Francesa. ${ }^{13}$

12 Frederick Cooper, Citizenship between Empire and Nation: Remaking France and French Africa, 1945-1960, Princeton; Oxford: Princeton University Press, 2014.

13 Tradução livre de “outre mer”, o termo “além-mar” é mencionado por representar uma denominação datada e referente ao tempo de existência da União Francesa, entre 1946 e 1958. Ele é utilizado para nomear o grupo ou os grupos de intelectuais oeste-africanos que dirigiam e ocupavam o centro das discussões no interior da Présence Africaine no período estudado, pois estes se reconheciam por meio do termo em muitas das fontes, principalmente nos primeiros números da revista, antes de 1949. Surge, por exemplo, como o definidor da intelectualidade que a publicação 
As conflituosas relações entre a França e os protetorados da antiga Indochina fortaleciam, desde $1946,{ }^{14}$ os argumentos usados para sublinhar a falha em implementar a nova política de integração gradativa das antigas colônias. Em 1954, o país europeu foi finalmente derrotado belicamente em Dien Bien Phu e perdeu sua influência sobre os antigos protetorados do Vietnã, do Laos e do Camboja, aumentando as incertezas em torno da vida útil da União Francesa também na opinião pública do Hexágono.

Do ponto de vista de intelectuais e políticos africanos e europeus, o momento era de impasse e de incansável debate sobre o futuro das relações entre os povos da União Francesa e a antiga metrópole. Não por acaso, o período era de maior poder de barganha por parte dos representantes de além-mar mesmo no cenário interno francês. Isso se torna ainda mais compreensível quando pensamos no conflito bélico iniciado na Argélia, em 1954, um dos mais violentos confrontos do século XX, e na saída oficial do Marrocos e da Tunísia da condição de Estados associados à União Francesa, em 1956. Ao lado do acirramento da ofensiva francesa contra as forças da Frente de Libertação Nacional na Argélia, nos anos de 1955 e 1956, havia uma tentativa de aproximação do governo central aos representantes políticos sul-saarianos e a suas demandas. ${ }^{15}$

procurava atingir em seu primeiro artigo de apresentação, assinado por Alioune Diop, intitulado “Niam n'goura ou les raisons d'être de la Présence Africaine”, publicado no número 1, de 1947. Embora o vocábulo seja gradualmente abandonado ao longo dos anos 1950 no interior da Présence Africaine, permanece como um marcador para a bancada de deputados representantes de departamentos e territórios de além-mar (départements e territoires d'outre mer) ao longo de todo o período aqui estudado, sendo que parte desses deputados escreveu para ou esteve diretamente envolvido na publicação da Présence Africaine, o que guiou a escolha por seu uso neste artigo.

14 Durante os debates da Assembleia Constituinte, em 1946, a Indochina surgiu como uma das exceções jurídicas na nova política para a França do além-mar. Assim como o Marrocos e a Tunísia, os territórios da Indochina eram ligados à França como protetorados, e não como colônias. Dessa forma, sua inserção na União Francesa deveria se dar por meio da noção de "Estado associado". No mesmo período, o poder de Ho-Chi-Minh crescia no Vietnã, e o líder político se negou a ceder poder de decisão para a potência europeia, que perdeu influência na região rapidamente ao longo da década de 1950. Cooper, Citizenship between Empire and Nation, pp. 55-61.

15 Segundo Frederick Cooper, referindo-se à criação da "Loi-cadre”, em 1956, tratava-se de dois aspectos de uma mesma política, “imagens espelhadas”. Cooper, Citizenship between Empire and Nation, p. 212. 
Para o escritor e político camaronês François Sengat-Kuo, em artigo publicado no número 3 da Présence Africaine, de 1955, dois pontos imbricados delimitavam a questão. Tratava-se da admissão do fracasso da Constituição de 1946, seguida da constatação de "que a França, no mundo moderno, não saberia conservar sem a África seu lugar de grande potência”. ${ }^{16} \mathrm{Na}$ análise de Sengat-Kuo e de seus interlocutores, a África era o celeiro de matérias-primas que a França, assim como o resto da Europa, necessitava para fazer frente à produção dos Estados Unidos e evitar os gastos em dólar. Mas mesmo na Europa não havia, no cenário pós-Segunda Guerra Mundial, consenso quanto à legitimidade dos interesses coloniais, e a França temia as ingerências do resto do continente e dos EUA. Crescia o valor simbólico da ideia de que o equilíbrio internacional era ameaçado pela política colonial, o que, como já apontava Sengat-Kuo, deixou a França em uma posição de fragilidade diante de economias crescentes e mais poderosas, como a da Alemanha Ocidental. ${ }^{17}$ Nessa nova configuração, o poder de intervenção de representantes e movimentos sociais asiáticos e africanos na Assembleia Nacional francesa crescia, à semelhança de palcos internacionais como Bandung.

Toda a avaliação de Sengat-Kuo, feita a partir de citações retiradas de revistas contemporâneas à Présence Africaine, apontava para sentidos então compartilhados sobre a importância dos países de fora do centro para a manutenção e a estabilidade das grandes potências. Tratava-se da noção de “equilíbrio mundial”, consagrada pela criação da Organização das Nações Unidas (ONU) em 1945, e usada na crônica do camaronês para fundamentar propostas de abandono da União Francesa e de radicalização da agenda de partidos políticos oeste-africanos em torno da independência, transitando entre contextos globais e locais.

16 François Sengat-Kuo, “A travers les revues européennes: La France fait son examen de conscience ou ‘le Fédéralisme sauvera-t-il l’Union Française”, Présence Africaine, n. 3 (1955), p. 86.

17 Sengat-Kuo, “A travers les revues européennes”, p. 87. 
Os pontos elencados pelo autor mostram a maneira como temáticas tais como política internacional, crítica ao colonialismo e projetos de futuro para o continente africano caminhavam juntas nas páginas da Présence Africaine. Em meados dos anos 1950, a instituição fundava novas políticas editoriais e procurava dar maior visibilidade a suas bandeiras e a seu poder enquanto interventora na cena pública na África do Oeste. Sem abandonar um discurso marcado pelo engajamento intelectual e pela concentração em temáticas culturais, a organização do periódico passava a fazer escolhas que expunham leituras do cenário internacional e uma agenda cada vez mais direta sobre a responsabilidade do intelectual negro na modificação de suas sociedades, para além do campo das artes ou da literatura. A leitura de que, na conjuntura posterior aos conflitos de 1939-1945, terminados com as bombas lançadas em Hiroshima e Nagasaki, o temor dos grandes embates armados era amplo e que, por isso, os territórios vistos como periféricos emergiam como atores necessários para a construção da paz, povoava planos de protagonismo intelectual, de independência política e até de formação de uma solidariedade internacional que garantisse sua efetividade e perenidade, tanto interna quanto externamente à África. ${ }^{18}$

Nesse contexto, a diretoria da Présence Africaine propõe a realização de um encontro para promover o diálogo entre intelectuais negros de todo o mundo, reinscrevendo os termos do internacionalismo à la Bandung. Não por acaso, é 1956 o ano em que sai do papel o Primeiro Encontro de Escritores e Artistas Negros. ${ }^{19}$

18 Lee, Making a World after Empire, pp. 5-19; Tullo Vigevani, Terceiro Mundo: conceito e história, São Paulo: Editora Ática, 1994; Odd Arne Westad, The Global Cold War: Third World Interventions and the Making of Our Times, New York: Cambridge University Press, 2005.

19 O documentário Lumières Noires, dirigido por Bob Swain e lançado em 2006, trabalha largamente como as tensões causadas pela Guerra Fria e pela crise da União Francesa constituem uma moldura de incertezas para as negociações que antecedem o evento de 1956. No entanto, cabe ponderar que, paradoxalmente, a possibilidade de sua realização se inscreve na mudança de posicionamento do Hexágono diante da elite política e intelectual sul-saariana, em grande medida fundamentada pelo temor do surgimento de novos conflitos bélicos e lutas de independência, a exemplo dos acontecimentos no norte da África e no sudeste asiático. 


\section{Algumas discussões no Primeiro Congresso de Escritores e Artistas Negros}

Em 1956 foi realizado, com a promoção da Présence Africaine, o Primeiro Congresso de Escritores e Artistas Negros. Esse evento marcou o início do engajamento da revista e editora na realização de congressos e seus congêneres, que se tornam atividades de destaque na década de 1960, com a mobilização de artistas, escritores e intelectuais negros. A bandeira dos grandes encontros culturais e intelectuais é uma das maneiras pelas quais a Présence Africaine extrapola sua dimensão escrita para atuar como uma instituição.

O congresso de 1956 está conectado com a já citada Conferência Afro-Asiática de Bandung, de 1955, para além de sua proximidade temporal. O evento promovido pela revista e editora, em Paris, herdava a apropriação da linguagem diplomática e a ampliação do cenário de negociação e de seus possíveis participantes, consagradas no ano anterior, na Indonésia, mas ao mesmo tempo modificava essa herança.

Segundo o número especial triplo 8-9-10 da Présence Africaine, lançado em novembro de 1956, ao dar início aos trabalhos no auditório Descartes, na Universidade de Paris-Sorbonne, no dia 19 de setembro de 1956, o diretor Alioune Diop foi o primeiro a chamar a atenção para a ligação com os acontecimentos emblemáticos de Bandung:

Esse dia será lembrado por muito tempo. Se Bandung constitui para as consciências não europeias o evento mais importante desde o fim da guerra, eu acredito poder afirmar que esse primeiro Congresso Mundial dos Homens de Cultura negros representará para nossos povos o segundo evento desta década. ${ }^{20}$

20 Alioune Diop, “Discours d’ouverture”, Présence Africaine, n. 8-9-10 (1956), p. 9. 
Para Alioune Diop, o Primeiro Congresso de Escritores e Artistas Negros era uma continuação e uma decorrência de Bandung. Não era a primeira vez que intelectuais da “África Negra” se apresentavam ao lado de seus pares vindos dos Estados Unidos da América e das Antilhas, de onde saíram os principais participantes dos congressos pan-africanistas de antes da Segunda Guerra Mundial. A diferença foi que o protagonismo político de produção desse evento foi assumido por africanos, através de uma instituição criada e dirigida por intelectuais nascidos na África, a Présence Africaine. ${ }^{21}$ Além disso, o congresso seria o primeiro evento desse tipo interessado oficialmente na cultura. Tratava-se, para Alioune Diop, de assumir a cultura como uma ferramenta essencial para aprofundar o diálogo iniciado em Bandung e mitigar os silêncios de outrora. E o intelectual negro e africano surgia como seu principal agente individual:

Nós vamos, essencialmente, enunciar e avaliar, juntos, as riquezas, a crise e as promessas de nossa cultura. O Congresso terá o mérito, também, eu espero, de revelar e de oferecer à admiração do mundo os talentos certamente variados, e que só eram escondidos na sombra até agora pelo silêncio em concerto das potências coloniais e do racismo. Mas como dar voz ao mundo negro e a seus escritores quando se sabe que o menor canto, mesmo que nem seja profundamente sentido pelo autor, esconde uma potência naturalmente explosiva que coloca em questão as bases da ordem colonial, as próprias estruturas do universo ocidental e do mundo? Não se enganem. Nós vivemos em uma época na qual os artistas dão testemunho e na qual eles são todos mais ou

21 O chamado V Congresso Pan-africanista, realizado em 1945, em Manchester, já conta com protagonismo de atores africanos e, além disso, as pautas ligadas a um certo anticolonialismo, que entendia se constituir em consonância com questões africanas, permearam o internacionalismo negro nas primeiras décadas do século $\mathrm{XX}$, quando o movimento ainda era mantido por uma imensa maioria de ativistas caribenhos e estadunidenses (cf. Alvarado, “A África deve se unir?”, p. 216-249). O destaque aqui, porém, vai para o ineditismo de um evento cuja força de mobilização parte da autoridade de uma instituição criada por uma elite intelectual e política africana que se estabelece como um centro de articulação do cenário intelectual negro atlântico, a Présence Africaine. 
menos engajados. É preciso tomar partido; toda grande obra de um escritor ou de um artista africano testemunha contra o racismo e o imperialismo do Ocidente. E isso permanecerá assim enquanto não se substituir as tensões que desequilibram o mundo por uma ordem cuja instauração seja a obra livremente construída dos povos de todas as raças e de todas as culturas. ${ }^{22}$

A ligação entre o Primeiro Congresso de Escritores e Artistas Negros e a Conferência Afro-Asiática foi destacada também nas contribuições de outros participantes, como Jacques Rabemananjara, Léopold Sédar Senghor e Cedric Dover. ${ }^{23}$

Para o político malgaxe Rabemananjara, "Bandung, como um gongo, foi o sinal para o fim espetacular de um monólogo de vários séculos”, ${ }^{24}$ e o papel do Primeiro Congresso era corrigir a pouca presença africana em 1955: "Só uma nota falta no concerto: a nota africana. Quando o continente negro desenvolverá, ele também, em torno dos principais problemas de nosso tempo, suas próprias variações, suas melodias regionais?”25 Qual contribuição específica o continente africano poderia trazer ao recomeço da conversação entre os povos? Segundo Rabemananjara, essa pergunta permanecia em aberto e sobre ela deveriam se concentrar os esforços durante o congresso. No entanto, esse não parecia um objetivo óbvio para outros

22 Diop, "Discours d'ouverture", p. 17.

23 Cedric Dover era indiano, filho de uma indiana e de um inglês. Sua formação foi principalmente nas áreas biológicas e seu interesse na noção de "raça” e "mestiçagem” o aproximou de escritores pan-africanistas estadunidenses. A presença de Dover em si já era uma repercussão de Bandung, uma vez que ele era o único membro de uma “delegação” asiática na ocasião. Em sua apresentação, no terceiro dia, Dover defendeu uma visão racialista de cultura, atrelando o conceito à ideia de uma unidade negra e propondo que o futuro pós-independência seria de maior aproximação e até de criação de uma federação entre as nações negras africanas. Nessas mudanças políticas, o intelectual teria o papel central de articulador. Conferir Cedric Dover, "Culture and Creativity”, Présence Africaine, n. 8-9-10 (1956), pp. 281-300.

24 Jacques Rabemananjara, “L’Europe et nous”, Présence Africaine, n. 8-9-10 (1956), p. 21.

25 Rabemananjara, “L’Europe et nous”, p. 22. 
participantes, e o impasse em torno de alguns conceitos em que se baseavam o encontro tomou grande parte das atenções e do tempo.

A publicação especial das atas do congresso feita pela Présence Africaine, principal fonte utilizada neste artigo, vinha com a divisão por delegações das personalidades convidadas que haviam comparecido, o que remete aos códigos da diplomacia internacional. No entanto, já a organização desses agrupamentos demonstrava que a adoção do modelo de Bandung não implicava uma adesão à ideia de nação como foco único da agenda a ser elaborada no congresso de 1956. Na lista estavam os Estados Unidos da América, Barbados, Jamaica, Cuba, Brasil, Haiti, Martinica, Guadalupe, Nigéria, Serra Leoa, Angola, Moçambique, Madagascar, Congo Belga, África do Sul, Senegal, Daomé (atual Benim), Costa do Marfim, Sudão Francês (atual Mali), Níger, Togo, Camarões, África Equatorial Francesa e Índia. Ao todo, 23 grupos, dentre os quais estavam representados Estados-nação, como EUA, Índia e Brasil, territórios franceses de além-mar (territoires d'outre mer, TOM), como o Senegal, o Daomé e a Costa do Marfim, estados associados à França, como Togo e Camarões, e unidades administrativas coloniais inteiras, como era o caso da África Equatorial Francesa. A presença de distintas categorias e atores coletivos como interlocutores internacionais demonstrava a multiplicidade de projetos e agentes políticos circulando no interior do Primeiro Congresso, mesmo em um contexto no qual Bandung, consagrando a agência de Estados centralizados, havia sido amplamente recebido e era afirmado como antecedente e fonte de legitimação.

Essas diferentes formas de agrupamento e apresentação dos chamados "delegados" nas atas, que - a se levar em consideração o nome do Primeiro Congresso - eram "escritores e artistas" independentes, e não representantes de organizações políticas, apontam para a convivência de diferentes referências de solidariedade internacional no interior do evento e em trânsito na intelectualidade presente. Encontravam-se ideais de unidade racial, mas também representações que implicavam a imagem da soberania estatal. Por um lado, nota-se aí 
a agência dos organizadores do evento na imaginação de soluções para conciliar diferentes projetos de como deveria ser uma unidade intelectual internacional organizada em torno de pautas como o anticolonialismo e o antirracismo. Por outro lado, porém, as discussões e até embates que seriam levantados durante os quatro dias de apresentações em torno de elementos-chave para a realização dos objetivos descritos por Alioune Diop na citação anterior denotavam os perigos e as tensões geradas pela pouca coesão entre os grupos e bandeiras políticas reunidas. A noção de cultura, usada na fala de Diop como uma fonte de unidade, levanta conversas emblemáticas nesse sentido.

Esses pontos de partida distintos foram notados e permanecem registrados nas atas e em relatos sobre o acontecimento. Um caso emblemático é o artigo "Princes and Power", publicado pelo repórter estadunidense James Baldwin, na Encounter, de janeiro de 1957, sobre o Primeiro Congresso de Escritores e Artistas Negros, ao qual havia comparecido como correspondente. Ao descrever o clima que antecedeu a formação da comissão que escreveu o comunicado oficial do evento, Baldwin afirma:

Nessas circunstâncias, era um empreendimento complicado pelas quase indefiníveis complexidades do termo "cultura”, pelo fato de que nenhuma declaração coerente havia sido feita considerando a relação das culturas negras entre si e, finalmente, pela necessidade, que se manteve ao longo da conferência, de evitar os assuntos políticos. ${ }^{26}$

A instância criadora ou interventora, o lugar e o autor de sua enunciação e a dimensão da identidade e da coletividade com a qual deveria se relacionar a "cultura”, mais exatamente a "cultura negra”, foram intensamente debatidos, sem muitos consensos.

26 James Baldwin, "Princes and Powers: Letter from Paris”, Encounter, jan. 1957, p. 59. 
Segundo Baldwin, a centralidade deste conceito nos debates era proposital e vinha como uma diretriz do evento: ${ }^{27}$ o primeiro dia seria dedicado a um inventário das culturas africanas, o segundo a uma constatação da crise dessas culturas, e o terceiro a uma apreciação de suas perspectivas futuras. A "cultura" emergia como tema central não apenas devido à vocação de seus participantes e da própria Présence Africaine, mas como tentativa de driblar o clima de desconfiança que cercou o congresso desde seus preparativos. De certa forma, optar por falar em "cultura” era evitar tocar diretamente em temas políticos, como o conflito entre França e Argélia que se iniciara em 1954 e cuja referência iria de encontro aos termos tácitos das negociações que permitiram a realização do evento em plena Sorbonne. Mesmo assim, como os debates comprovariam, a "cultura" estava longe de configurar o consenso apontado, ou pelo menos desejado, por Alioune Diop em seu discurso inicial, e parte das questões em jogo vinha justamente da imbricada relação entre diferentes propostas e entendimentos do conceito e as agendas políticas e sociais de seus enunciadores.

Em alguns momentos, as abordagens dadas ao conceito foram mais pragmáticas, ligadas à ideia da cultura como arma para a criação de novos Estados independentes e de solidariedade transnacional. Um caso bem evidente desse tipo de leitura do papel da cultura e da unidade que se poderia promover a partir de sua interpretação e uso no continente africano foi a apresentação do egiptólogo senegalês, Cheikh Anta Diop, no terceiro dia do congresso, intitulada "Apports et perspectives culturels de l'Afrique". O estudioso havia lançado no ano anterior o livro Nations nègres et culture, sobre a origem africana e negra da civilização do Egito Antigo, com ampla recepção - embora nem sempre positiva - na academia francesa e várias vezes citado durante o evento de 1956. Em sua comunicação, Anta Diop defendeu que "essa noção [de cultura] é ligada, em minha opinião, à emergência de um Estado multinacional que abarque a quase

27 Baldwin, “Princes and Powers”, p. 59. 
totalidade do continente”. ${ }^{28}$ Para Anta Diop, portanto, uma apresentação das culturas africanas só era interessante na medida em que servisse ao propósito de mapear as características compartilhadas que favoreceriam as bases de um Estado multinacional na África: ${ }^{29}$

Por certo, no decorrer desta luta, as armas culturais serão desde já necessárias [grifo meu]; ninguém pode prescindir delas. Por isso há que forjá-las simultaneamente dentro da estrutura da nossa luta pela independência nacional. A cultura estará então essencialmente a serviço da luta de libertação nacional. ${ }^{30}$

Em outras ocasiões, porém, a argumentação se desenvolveu como uma descrição de elementos das culturas de populações da África, inserindo-se em uma tematização semelhante àquela feita nos primeiros anos da Présence Africaine. Um exemplo dessa abordagem foi a comunicação do linguista nigeriano E. L. Lasebikan, no primeiro dia, intitulada "The tonal structure of yoruba poetry”. Segundo nota na ata, a apresentação foi acompanhada por tambores. No texto, o autor discorre sobre a língua dos Yorubá, da qual dá três características principais: tonal, repleta de expressões vindas de onomatopeias e rica em possibilidades de criação de novas palavras. A partir dessas noções, o autor investigou alguns poemas yorubás quanto a sua estrutura formal e sua relação com o ritmo. ${ }^{31}$

Entre vários pontos de partida para compreender como a cultura deveria ser abordada, emergiram contradições opondo alguns dos principais intelectuais presentes. Assim, a “cultura negro-africana”,

28 Cheikh Anta Diop, “Apports et perspectives culturels de l'Afrique”, Présence Africaine, n. 8-9-10 (1956), p. 342.

29 Esse posicionamento foi ovacionado pela plateia. Segundo registra o jornalista James Baldwin em seu artigo sobre o evento, publicado no ano seguinte, a comoção causada por Anta Diop só perdeu para o efeito que as palavras de Aimé Césaire tiveram no público presente. Baldwin, "Princes and Powers", p. 59.

30 Anta Diop, “Apports et perspectives culturels de l’Afrique”, p. 342.

31 E. L. Lasebikan, “The Tonal Structure of Yoruba Poetry”, Présence Africaine, n. 8-9-10 (1956), pp. 43-50. 
percebida como original e independente, que foi apresentada na intervenção de Léopold Sédar Senghor, foi considerada, no dia seguinte, por Aimé Césaire, como impossível sob colonização e inviável antes da formação de instituições políticas livres.

Para esses últimos e vários outros dos presentes, delegados envolvidos diretamente no jogo político da União Francesa, a diversidade de posicionamentos podia ser tanto uma decorrência quanto uma causa das discordâncias sobre o lugar da soberania nacional, da liberdade política e da independência no futuro da África e dos povos negros. No caso oeste-africano, o debate apontava para um campo de decisões em aberto e muito mais variado do que poderia se esperar de um congresso frequentado por sua elite intelectual apenas quatro anos antes de 1960, ano em que todos os antigos territórios da África Ocidental Francesa (AOF) estariam oficialmente independentes. As propostas disponíveis em 1956 sobre os caminhos a tomar podiam ser contraditórias em vários níveis e denotavam discordâncias que rompiam as fronteiras entre o cultural e o político.

Nesse sentido, vale mencionar o levantamento de discussões que permearam o campo partidário da AOF no mesmo período, feito pelo historiador Frederick Cooper em Citizenship between Empire and Nation: Remaking France and French Africa, 1945-1960 (2014). No quadro traçado por Cooper, cidadania, independência, soberania e liberdade política são elementos de incansáveis embates e discordâncias entre partidos e figuras políticas de proa, como Aimé Césaire, Léopold Sédar Senghor, Mamadou Dia, Félix Houphouët-Boigny, Ahmed Sékou Touré e Madeira Keita, dentre outros. Com relação a esses atores, vale lembrar que alguns deles estavam presentes e ativos no Primeiro Congresso, e que todos eles foram várias vezes mencionados ou tiveram textos publicados na íntegra na Présence Africaine ao longo dos anos 1950 e 1960. Além disso, grande parte da argumentação de Cooper chama atenção para a maneira como a ideia de cidadania, central nas disputas entre defensores e detratores da manutenção das ligações políticas com a França, tinha na definição de pertencimento cultural seu principal elemento de definição. Isso tornava os debates sobre 
quem poderia ser inserido ou não em uma dada esfera cultural, ou sobre se é possível ou mesmo desejável que a ideia de Estado, nação e cultura se confundam, ainda mais direta e irrevogavelmente imbricados em polêmicas acaloradas, em que estavam em jogo projetos sobre os caminhos para o futuro político na África e nas Antilhas. ${ }^{32}$

Ao lado desses embates entre intelectuais oeste-africanos e do além-mar, e ligadas às polêmicas em torno da conceituação e da abordagem a dar à ideia de cultura, estavam as disputas sobre as justificativas para a seleção dos delegados e delegações que se encontravam presentes. Evitar temas diretamente políticos e afirmar a necessidade de um debate cultural também visava minimizar as discordâncias com relação ao cenário macro, nesse caso, de amplitude global e de implicações maximizadas pelos conflitos da Guerra Fria. Nesse sentido, como acomodar os intelectuais americanos, principalmente os estadunidenses, no “espírito de Bandung”?

Para alguns, como o haitiano Jean Price-Mars - partícipe de um dos primeiros movimentos culturais e intelectuais de construção de uma identidade e de uma estética negras no continente americano no século XX, o indigenismo haitiano -, tratava-se de um encontro baseado em uma dupla unidade: o compartilhamento da cor de pele e, ao mesmo

32 Cooper trabalha principalmente as disputas entre projetos de formação de uma federação que incluísse a França, planos de unidade federativa regional a partir do esqueleto da antiga AOF e a proposta de independência política nacional ligada aos territórios individualmente. Cada uma dessas proposições é acompanhada por conceitos de cidadania que envolvem a proclamação de unidades culturais distintas e, por vezes, em disputa, entre local, nacional, regional e até transcontinental. Para Cooper, a ideia da ligação entre cidadania política e pertencimento cultural é uma característica que remonta ao jogo político colonial francês no século XIX e constitui-se como parte central dos argumentos que serviram para excluir do campo político metropolitano os nascidos nas colônias francesas durante a Terceira República. Não por acaso, as reivindicações feitas pelos deputados de além-mar na criação da União Francesa, em 1946, passando pelo desaparecimento oficial do estatuto de colônia do texto constitucional francês e a abolição do Indigenato e do trabalho forçado, tinham como base a defesa de uma ideia de cidadania francesa política e extensiva, aalém da recusa à ideia da assimilação cultural e ao etnocentrismo nacionalista próprios de sua caracterização institucional anterior à Segunda Guerra Mundial. Da mesma forma, as falhas da Quarta República estariam ligadas ao fracasso francês em estender na prática e de forma completa a cidadania e os direitos de participação republicanos aos territórios de além-mar. Ver Cooper, Citizenship between Empire and Nation, pp. 125-164. 
tempo, da condição histórica de opressão dada pela escravidão e pela colonização, que era vista, em parte, como uma decorrência da atitude negativa do Ocidente diante dessa característica física.

Nós temos a pretensão de representar uma multidão imensa de seres humanos espalhados por uma grande parte da superfície terrestre e, particularmente, na África. Nós nos distinguimos todos ou quase todos por uma singularidade indelével - a cor mais ou menos escura de nossa pele, por ela ter sido por muito tempo - durante milênios - atingida pelo sol, segundo a imagem bíblica. É dessa singularidade de que se utilizou o mercantilismo odioso do século XVII para levar milhões de nossos ancestrais para a servidão do outro lado do Atlântico. ${ }^{33}$

No já mencionado discurso de abertura de Alioune Diop, esses mesmos argumentos são usados para significar as alianças que estavam em construção. A herança histórica vinda da escravização de indivíduos africanos e de seu transporte forçado para o continente americano sob dominação colonial teria como resultado a criação de laços biológicos e culturais transatlânticos: "Negros dos EUA, das Antilhas e do continente africano, qualquer que seja a distância que, às vezes, separa nossos universos espirituais, nós temos em comum, incontestavelmente, que descendemos dos mesmos ancestrais”. ${ }^{34}$

A inserção de comunidades americanas no evento, portanto, seria uma decorrência natural das ligações transatlânticas forjadas pela diáspora africana. Essa postura pressupunha que as relações históricas entre a América e a África tinham forjado uma unidade duradoura que comportava o compartilhamento de ancestrais e de origens culturais.

Essa teorização mostra outra maneira pela qual o Primeiro Congresso se apropriou e transformou o arcabouço de legitimação presente na Conferência de Bandung. No interior dessa perspectiva, ainda

33 Jean Price-Mars, “Scéance d’ouverture”, Présence Africaine, n. 8-9-10 (1956), p. 7.

34 Diop, “Discours d'ouverture”, p. 9. 
que parte de um Estado poderoso, para os organizadores do congresso, a comunidade negra estadunidense tinha uma situação que a posicionava como uma interlocutora natural. Assim, a quase ausência do continente asiático e a presença de uma delegação estadunidense se encontravam explicadas, e não deveriam ser um impeditivo para a celebração da herança de Bandung e de suas propostas quanto à fundação de uma solidariedade terceiro-mundista. A partir dessa perspectiva, a identificação entre os membros da diáspora negra na América e a ideia de união entre povos colonizados ou ex-colonizados foi alvo, por exemplo, do esforço teórico de autores como Diop, Senghor e Césaire. No entanto, este nem sempre foi recebido de forma positiva pelos intelectuais estadunidenses presentes.

Em 1956, o evento histórico considerado como fundador de laços significativos, à frente da colonização, foi o escravismo moderno, ocorrido entre os séculos XVI e XIX, gerando o trânsito de indivíduos escravizados entre o continente africano e a América. Como uma maneira de conciliar o eixo afro-asiático e o atlântico, a escravidão foi de alguma forma igualada ou ligada às mazelas do colonialismo do século XIX, principal pauta dos intelectuais africanos. Ou ainda, mais do que o colonialismo, foram o escravismo na América e a escravização na África os eventos fundadores a serem mobilizados de forma a legitimar os laços originais entre esses dois continentes, protagonistas do Primeiro Congresso. Essa tentativa é tangível no discurso de abertura de Alioune Diop, para quem o que unia os "povos negros" era o fato de "que todos eles conheceram e conhecem ainda, em sua maioria, o regime político-social chamado de colonização. Ele é equivalente, no nível dos povos, ao que a escravidão é em termos de indivíduo”. ${ }^{35}$

Uma abordagem semelhante, mas com maior ênfase no compartilhamento de uma unidade racial/cultural, é defendida por Léopold Sédar Senghor em sua apresentação "L’esprit de la civilisation ou les lois de la culture négro-africaine”, feita no primeiro dia do congresso. Essa comunicação é emblemática da tentativa de transformar a ideia de um

35 Diop, “Discours d'ouverture”, p. 10. 
compartilhamento cultural em denominador comum que permitisse mesclar referências políticas sabidamente divergentes em um diálogo harmonioso. Segundo Senghor, a ocasião era de trocar conhecimentos sobre a "cultura negro-africana” para munir os intelectuais negros presentes do saber necessário sobre sua originalidade cultural, o que deveria guiar sua produção artística. Em seu texto, Senghor procurava conjugar as repercussões do movimento terceiro-mundista com uma solidariedade dita racial através de uma abordagem cultural. O autor, que propôs construir uma federação dos territórios oeste-africanos com participação da França, sugestivamente não ligava a ideia de cultura negra a uma unidade nacional, mas sim a uma ampla e transcontinental comunidade racial e multinacional. ${ }^{36}$

Além disso, a apresentação de Senghor defendia o protagonismo político africano no interior da rede internacional de intelectuais negros que procurava fundar. Para o autor, os artistas e escritores negros deveriam retornar à África se quisessem tornar mais autêntica sua criação pessoal, que não podia mais ser individualista (nacionalista?), mas sempre forjada em consonância com os ideais de coletividade próprios das comunidades africanas, vistas como guardiãs do “espírito da civilização” negra. As riquezas existentes em "sua escultura, sua música, sua dança, sua literatura e sua filosofia tradicionais" ${ }^{37}$ eram os elementos que tinham levado ao recente reconhecimento da riqueza da África no continente europeu, "isto é, se os escritores e artistas nègres de hoje querem completar a obra no espírito de Bandung, eles devem frequentar a escola da África negra”. ${ }^{38}$ Para ele, portanto, a explicação para a reunião era clara:

36 François Sengat-Kuo tem Senghor como alvo em vários de seus textos publicados na Présence Africaine. Em artigo de 1958, o camaronês cita o texto do parlamentar senegalês, publicado em 1956, ano do Primeiro Congresso, na revista francesa Politique étrangère, como exemplo de posição contrária a um rompimento político entre a França e os territórios africanos: "falamos de independência para conseguir, na verdade, como confessa o Sr. Senghor, 'desviar da pura e simples reivindicação de independência’”. François Sengat-Kuo, “La loi-cadre et les partis politiques africains”, Présence Africaine, n. 18-19 (1958), p. 110.

37 “L'esprit de la civilisation ou les lois de la culture négro-africaine”, Présence Africaine, n. 8-9-10 (1956), p. 51.

38 Senghor, “L'esprit de la civilisation”, p. 52. 
O espírito de Bandung é a preocupação que manifestam, então, os povos afro-asiáticos de fortalecer, através da afirmação, sua personalidade, para não entrar de mãos vazias no "encontro do dar e do receber”. Pois a civilização mundial - e, antes disso, a paz - será a obra de todos ou não será. E como crer que o espírito de Bandung, que é, para nós, antes de mais nada, um espírito de cultura, não sopra também sobre os povos da América, singularmente, sobre os nègres? Pois a raça negra, mais que qualquer outra, foi vítima das grandes descobertas. O Renascimento europeu se edifica sobre as ruínas da civilização negro-africana, a força americana criou corpo a partir do suor e do sangue nègres. Esses duzentos milhões de mortos que o tráfico de nègres custou à África. Mas quem enumerará as riquezas culturais perdidas? Graças a Deus, a chama não se apagou, o fermento permaneceu no fundo dos corações e dos corpos assassinados, e permite hoje nosso Renascimento. ${ }^{39}$

Ao longo de sua apresentação, Senghor buscou reunir traços culturais que entendia como compartilhados pelo conjunto dos povos africanos e igualmente visíveis na diáspora na América, inserindo o Novo Mundo em sua “civilização negro-africana” e no “espírito de Bandung”. Este último era entendido como a euforia gerada pela entrada no concerto das nações através da valorização das "personalidades” culturais/raciais originais afro-asiáticas, o que dava a tutela do evento de 1956 às sociedades da África e a seus representantes, os “escritores-artesãos”.

Para Senghor, as características físicas e psicológicas descritas como negras teriam resistido tanto ao trauma da escravidão moderna quanto à colonização da África nos séculos XIX e XX e não estavam à espera da independência política para se concretizar. No texto, um fundo cultural transcontinental e, acima de qualquer outra forma de divisão, naturalmente racial, era anterior, ultrapassava e sobrepunha qualquer

39 Senghor, “L’esprit de la civilisation”, p. 51. 
opressão histórica. Segundo o então deputado senegalês na Assembleia Nacional francesa, a “civilização e a cultura negro-africanas” haviam sobrevivido a todas as tentativas de destruição a que tinham sido expostas, e deveriam ser, devido a isso, vislumbradas como fontes inescapáveis naquele momento em que a ordem mundial era repensada.

Os discursos lidos durante o dia 19 de setembro na Universidade da Sorbonne, em Paris, em 1956, mobilizavam com maior ou menor ênfase a ideia de uma identidade cultural compartilhada por todos os povos de origem africana. Os marcadores utilizados para mapear essa ancestralidade em comum eram a cor da pele, o motivo de sua dispersão inicial e, ao mesmo tempo, a necessidade de sua afirmação e positivação naquele momento de expropriação e violência infligida por atores externos, identificados com a Europa e com a raça branca. As construções destacadas até aqui, portanto, inseriam o eixo atlântico na perspectiva do movimento afro-asiático, de solidariedade entre populações que haviam permanecido fora do palco das decisões diplomáticas na primeira metade do século XX. De maneira complementar, por meio de uma percepção da história mundial vigente em movimentos intelectuais anticoloniais negritudianos e pan-africanistas, comparava-se a dominação e a subjugação de um país por outro às relações raciais assimétricas e ao racismo existentes dentro de nações americanas representadas no congresso. Porém, para alguns delegados americanos presentes no Primeiro Congresso de Escritores e Artistas Negros, essa ligação não era tão evidente, tampouco o papel deles no evento.

Após a apresentação de Senghor, houve um intervalo e os delegados voltaram a se reunir durante a noite para uma rodada de debates. A participação de Richard Wright nesse momento descortinou aos presentes os primeiros conflitos em torno da formação de uma única identidade que abarcasse o continente africano e as diásporas. Incomodado pela apresentação do poeta senegalês, o escritor se questiona:

Isso não é hostilidade; isso não é criticismo. Eu estou fazendo um questionamento de irmãos. Pergunto-me onde eu, um negro americano, 
condicionado pela áspera, industrial e abstrata força do mundo ocidental, que usou severos preconceitos políticos contra a sociedade (que ele elucidou de forma tão brilhante) - onde eu estou em relação a esta cultura? Se eu fosse de outra cor ou outra raça, eu poderia dizer, "Tudo isso é muito exótico, mas isso não é diretamente relacionado a mim”, e eu poderia deixar isso para lá e tal. Eu não posso. O mundo moderno nos moldou pelo mesmo molde. Eu sou negro e ele é negro; eu sou americano e ele é francês, e então, lá está você. E mesmo assim há um cisma em nossa relação, não político, mas profundamente humano. Tudo que eu já escrevi e disse foi em defesa da cultura que Léopold Senghor descreve. Por quê? Porque eu não quero ver pessoas machucadas; eu não quero que o sofrimento seja aumentado e agravado. E, mesmo assim, se eu tento me encaixar nessa sociedade, me sinto desconfortável. ${ }^{40}$

Qual o papel do intelectual negro estadunidense na luta encampada pelas sociedades africanas? A identificação histórica entre americanos e africanos seria suficiente para engajar indivíduos vindos de lugares tão diversos nos mesmos ideais? Richard Wright se considerava um homem ocidental e não se via no "espírito da civilização negro-africana” que Senghor havia descrito. Mais profundamente, Wright se perguntava se realmente o tom otimista do poeta fazia sentido e se as culturas então celebradas deveriam ser preservadas ou não.

Nós devemos fazer uma circunferência em torno dessa cultura, um forte ocidental para protegê-la e deixá-la intacta, com todas as múltiplas implicações políticas que isso envolve? Ou esta cultura deve sofrer o destino de todas as culturas de tipo poético e indigène e "ir com a corrente”? ${ }^{41}$

O autor de Black Boy não acreditava na validade de um arcabouço cultural transcontinental e mantinha a nação como maior fonte de

40 “Débats”, Présence Africaine, n. 8-9-10 (1956), p. 67.

41 "Débats", p. 68. 
identificação coletiva e verdadeiro espaço de formação cultural dos indivíduos. Para ele, a explanação feita por Léopold Sédar Senghor não inspirava nos americanos presentes a percepção de compartilhamento cultural, mas sim de profunda alteridade. A nação também surgia como ponto central para o escritor haitiano Jacques Stéphen Alexis, que tomou a palavra após Wright no debate e, de forma semelhante, colocou em xeque a dissertação de Senghor, porém por um caminho bem diferente do apontado pelo estadunidense:

Na verdade, quando nós dizemos “a cultura”, de quais dados nós falamos?

Nós falamos de um dado com alguma relação com um solo, com um povo, com uma história? Ou falamos de um conjunto de territórios, de um conjunto de povos, de um conjunto de histórias que foram mais ou menos contemporâneas, mas que têm indiscutíveis diferenças? ${ }^{42}$

Alexis formulou em termos bem claros as diferentes concepções de cultura que se faziam perceptíveis nesse dia inicial do Primeiro Congresso, ainda sem serem nomeadas. Segundo o escritor, a comunicação de Senghor tratava as sociedades da África como um conjunto indefinido de formações políticas e sociais, o que seria injusto com sua diversidade e semelhante ao discurso colonialista sobre o continente. Além disso, o tempo, para o haitiano, era o da criação de nações, e era com isso que os movimentos anticoloniais deveriam lidar, não com inventários gerais e abstratos sobre as culturas africanas:

É preciso, portanto, colocar os problemas da cultura em função da independência nacional - em função da formação de nações.

O mundo - como todos nós dissemos - é uma encruzilhada. É Bandung, um sino que ressoa, que indica não somente que queremos que nossas culturas apareçam como coisas grandes e belas, mas que

42 “Débats", p. 68. 
indica, igualmente, que os povos querem vir à vida como organismos constituídos. E são esses organismos constituídos que serão a base das culturas nacionais em formação. Fora dessa noção, todas as declarações de amor à cultura são apenas exercícios verbais que só aumentam o problema. ${ }^{43}$

De forma sugestiva, Alexis mobilizou Bandung como a representação de que a resposta para os movimentos anticoloniais deveria ser a luta pela formação de nações. Segundo ele, os povos da África queriam se tornar “organismos constituídos”, o que seria a base para culturas nacionais recém-nascidas. Não há como evitar pensar sobre o peso que o conhecido posicionamento político de Senghor, em 1956, então contrário às independências imediatas na África do Oeste, pode ter tido para as discordâncias apresentadas por Alexis, autor haitiano ligado ao marxismo, à explanação sobre uma "cultura negro-africana” que não se ligaria necessariamente à garantia prévia de soberania nacional, feita pelo senegalês.

À manifestação de Alexis durante os debates, Senghor respondeu com o argumento de que estava apenas seguindo o planejamento do Primeiro Congresso ao proceder a um inventário da “cultura negro-africana”. No entanto, para o escritor haitiano, a questão não era sobre fazer ou não um levantamento das “culturas negro-africanas”, mas sobre o que se encontrava delimitado por esse conceito. Decidir sobre isso era importante por incidir diretamente sobre a forma como eram encaradas as muitas comunidades negras dentro e fora da África. E, segundo Alexis, era historicamente inviável considerar que a identidade racial se sobrepunha a um pertencimento regional e, de maneira ainda mais forte, nacional.

Eu penso, na verdade, que não podemos, impunemente - e a intervenção de Richard Wright corrobora bem o que acabei de assinalar - declarar que existe uma cultura negro-africana global da qual devem ser testemunhas

43 “Débats”, pp. 70-71. 
todos os negros da Terra. Quanto ao fato da permanência de contribuições culturais, nós todos estamos de acordo em dizer que no Haiti, no Brasil, nos EUA, há elementos culturais que apresentam um parentesco com aqueles da África. Mas isso não implica, de forma alguma, que esta cultura negro-africana deve se encontrar em primeiro plano. Há culturas nacionais que são sobrepujadas, em um estágio superior, por culturas regionais. ${ }^{44}$

Esse conflito diante dos termos da unidade que se queria proclamar ao falar em "cultura negro-africana” era um tema delicado porque representava, para vários dos intelectuais presentes, a fundamentação de uma solidariedade política conforme preconizada pelo pan-africanismo e pelo movimento da Négritude, bem como a base de alianças a serem constituídas. Não por acaso, Aimé Césaire, quando interfere na discussão entre Alexis e Senghor, tenta conciliar os ânimos afirmando que a ponderação feita pelo haitiano era óbvia e que a discussão era somente uma falha de comunicação:

Com efeito, nos perguntam, existe uma cultura negro-africana? Eu creio que há uma confusão, e que de fato existem as culturas nacionais: uma cultura do Senegal, uma cultura jalofa (digamos assim, para abreviar), enfim, muitas culturas africanas. Mas isso não impede que todas essas culturas apresentem entre si suas afinidades. ${ }^{45}$

Apesar dessa fala, porém, o poeta e político martinicano adotou em sua intervenção, intitulada “Culture et colonisation”, na tarde seguinte, segundo dia de apresentações, em 20 de setembro, uma leitura política distante da de Senghor e bem mais próxima das ponderações feitas por Alexis. Em sua explanação, Césaire defendeu que o colonialismo agia, enquanto regime, por meio do desmantelamento das culturas colonizadas como uma parte inerente de seu processo de dominação. Sua participação foi uma das mais esperadas e, segundo o repórter estadunidense

44 “Débats”, pp. 75-76.

45 “Débats", p. 73. 
James Baldwin, foi a que mais comoveu e arrancou aplausos da plateia. ${ }^{46}$ O discurso começou por uma introdução que retornava às discussões do dia anterior, como uma resposta. O poeta martinicano procurava resolver o impasse reiterando o princípio histórico que uniria África e América, mas concentrando-se sobre uma noção mais ampla do colonialismo, que aprofundava a semelhança entre o racismo no interior de um Estado independente e a dominação colonial:

Interrogámo-nos em particular sobre qual o denominador comum a uma assembleia que une homens tão diversos, como africanos da África negra e norte-americanos, antilhanos e malgaxes. A resposta parece-me evidente: esse denominador comum é a situação colonial. É um facto que a maior parte dos países negros vive sob o regime colonial. [...] E mesmo nossos irmãos americanos estão colocados, através do jugo da discriminação racial, de um modo artificial e no seio de uma grande nação moderna, numa situação que só se compreende por referência a um colonialismo que foi certamente abolido, mas cujas sequelas não deixam de ressoar no presente. ${ }^{47}$

Para Césaire, portanto, o que unia todos os envolvidos no congresso, inclusive as delegações americanas, era o "colonialismo”, e sua vivência do fenômeno naquele exato momento. Era, segundo o martinicano, impossível classificar a cultura negra sem antes falar do colonialismo, "pois todas as culturas negras se desenvolvem no momento actual dentro deste condicionamento particular que é a situação colonial ou semicolonial ou paracolonial” ${ }^{48}$ E, em uma tentativa de resolver os termos em torno de como abordar a cultura negra e as relações entre a solidariedade racial e a identidade nacional, Césaire insistiu em sua posição conciliadora do dia anterior:

46 Baldwin, "Princes and Powers", p. 58.

47 Aimé Césaire, “Cultura e colonização” in Manuela Ribeiro Sanches (org.), Malhas que os impérios tecem: textos anticoloniais, contextos pós-coloniais (Lisboa: Edições 70, 2011), p. 253.

48 Césaire, “Cultura e colonização”, p. 254. 
Mas, dir-me-ão, o que é a cultura? Importa defini-la para dissipar um certo número de mal-entendidos [...]. Por exemplo, houve quem se interrogasse acerca da legitimidade deste Congresso. Se é verdade, como se disse, que não há cultura a não ser a nacional, falar de cultura negro-africana não será falar de uma aberração? Penso que é bem verdade que apenas existe cultura nacional. Mas é evidente que as culturas nacionais, por muito particulares que sejam, se agrupam por afinidades. E esses grandes parentescos de cultura, essas grandes famílias de culturas, têm um nome: são civilizações. ${ }^{49}$

O desenrolar das discussões que se seguiram demonstrou, porém, que se tratava de mais do que um mal-entendido. Dessa vez, a comunidade negra estadunidense presente foi quem dominou os questionamentos, colocando em pauta os limites de seu engajamento no evento.

Para entender as cisões entre estadunidenses e outros delegados nessa ocasião, é importante considerar que o grupo convidado estava ligado à elite intelectual e econômica da luta legalista contra o segregacionismo nos EUA, representada, por exemplo, pela imagem do advogado John Davis, e possuía uma história e demandas que dificilmente se beneficiariam de uma apropriação das ideias de autonomia que faziam sentido na luta contra o colonialismo e mesmo para outros grupos de ativistas negros estadunidenses. ${ }^{50}$ Pode-se dizer que, destacando-se novamente o contexto internacional, a delegação que estava no Primeiro Congresso

49 Césaire, “Cultura e colonização”, p. 254.

50 A ideia de autodeterminação perpassa a história de mobilizações negras e antirracistas nos EUA desde o século XIX, inserindo-se em diferentes lutas e projetos de futuro. Nesse sentido, é possível pensar o apoio e adesão ao projeto de criação da Libéria, na segunda metade do século XIX, e até as ideias de Booker T. Washington em sua conhecida polêmica com William E. B. Du Bois, na passagem para o XX. Também os empreendimentos de Marcus Garvey e sua ampla repercussão entre certos grupos de classe média africano americanos, já nos anos de 1920, são um exemplo da força que o argumento da autodeterminação teve na imaginação de uma solução para o racismo sistêmico na sociedade estadunidense. Posteriormente, durante os anos de 1960 e 1970, diretamente em diálogo e sob influência de movimentos terceiro-mundistas e do internacionalismo socialista e comunista, lideranças como Stokely Carmichael e o chamado movimento Black Power pautariam os limites do legalismo liberal de parte do movimento 
precisa ser relacionada a algum nível de comprometimento com a política externa dos EUA no período e com a identidade de homens ocidentais. Para esses intelectuais, portanto, proclamar uma irrefletida solidariedade com movimentos anticoloniais e suas múltiplas adesões ideológicas poderia se tornar uma perigosa declaração de apoio a grupos com alianças que extrapolavam o capitalismo. Um tal posicionamento seria fortemente comprometedor na volta para casa. ${ }^{51}$

Sobre as tensões no cenário estadunidense, uma das mensagens lidas no início do evento, de William E. B. Du Bois, foi esclarecedora e, ao mesmo tempo, introduziu, desde os primeiros momentos, as dificuldades que acompanharam o encontro. As colocações do líder pan-africanista demonstravam que não havia consenso com relação à representatividade dos delegados presentes no auditório Descartes, em 1956:

Eu não estou presente na sua reunião hoje porque o governo dos EUA não me concedeu um passaporte para viajar para fora do país. Qualquer negro-americano que viaja para fora do país hoje deve evitar discutir as condições raciais nos EUA, ou dizer o tipo de coisa que nosso Departamento de Estado quer que o mundo acredite. O governo se opõe especialmente a mim, porque eu sou socialista e porque eu

pelos direitos civis, aproximando a situação social de populações negras nos EUA à de populações colonizadas ou vivendo em países considerados como de Terceiro Mundo.

51 Os primeiros anos da Guerra Fria nos EUA são marcados por um clima político de forte condenação a movimentos e posicionamentos de esquerda, muitas vezes representado pelas perseguições realizadas pelo senador Joseph McCarthy até a segunda metade da década de 1950. Nesse contexto, o movimento pelos direitos civis da população negra estadunidense acabou em posição paradoxal. Na medida em que os EUA queriam projetar uma imagem internacional de centro do chamado "mundo livre" (free world), organizações que encabeçavam lutas, principalmente jurídicas, contra as leis de segregação tiveram uma maior visibilidade interna. No entanto, havia uma tênue linha entre a representação do movimento como promotor de críticas importantes para a melhoria do país e a percepção de suas ações como subversivas e ligadas a planos externos de desestabilização dos EUA. Ver Manfred Berg, "Black Civil Rights and Liberal Anticommunism: The NAACP in the Early Cold War", The Journal of American History, v. 94, n. 1 (2007), pp. 75-96. 
acredito na paz com os Estados comunistas, como a URSS, e em seu direito de existirem em segurança. ${ }^{52}$

A adesão de Du Bois a uma plataforma de esquerda, que dificultava suas articulações dentro dos EUA, então dominados pelo anticomunismo, mostra como o cenário político e as articulações das lutas estadunidenses em torno das pautas da desigualdade racial eram bem diversas, envolvendo discordâncias sobre o peso a se dar, por exemplo, às relações entre a opressão sistêmica racista e o próprio funcionamento de uma sociedade de classes capitalista. A se levar em consideração a denúncia de Du Bois, para estarem presentes no Primeiro Congresso, os delegados estadunidenses deveriam ser considerados pela polícia ideológica do Departamento de Estado como sujeitos engajados em uma postura nacionalista, o que implicava uma alta dose de intolerância diante de representações externas dos conflitos existentes no interior da sociedade estadunidense, ainda mais quando feitas por um ex-militante do Partido Comunista francês, como Césaire. Todas essas dimensões da participação de uma delegação estadunidense no evento se inserem de forma mais ampla na Guerra Fria. Assim, nos debates da noite do segundo dia, o posicionamento de Aimé Césaire seria também alvo de controvérsias. É Mercer Cook que inicia as ponderações da delegação estadunidense às falas do martinicano:

O sr. Césaire bem disse que nós, negros americanos, temos um estatuto de semicolonizados, ok; mas eu me sinto, depois de 7 horas, cada vez menos solidário a meus congêneres africanos. E isso me incomoda, isso me faz muito mal.

Eu gostaria de pedir ao sr. Césaire alguns esclarecimentos: é para discutir esse colonialismo, e somente esse colonialismo, que estamos aqui? Nós discutimos o colonialismo; será que as outras questões sobre outros aspectos da cultura não são só pretextos para esse congresso? ${ }^{53}$

52 “Messages”, Présence Africaine, n. 8-9-10 (1956), p. 383.

53 “Débats”, p. 213. 
Em seguida, John Davis toma a palavra para também interpelar Césaire. Assim como a Cook, o andamento das discussões o incomodava devido à maneira como os negros estadunidenses eram representados:

Primeiro, eu quero saber o que ele quer dizer quando fala que a situação do Negro na América é melhor entendida em termos de colonialismo? Se ele quer dizer em termos de raça, eu consigo entender. Nossa posição, parece-me, é a de uma minoria no país. Isso acontece com muitos grupos em muitos países. Às vezes, é uma minoria religiosa; às vezes é uma minoria racial.

O que os Negros americanos querem - eu preciso deixar bem claro e têm lutado muito e com grandes sacrifícios, tanto pessoais quanto em termos de sangue, para conquistar, é o estatuto de cidadania completo e igualitário; e, desde 1936, nós fizemos enormes progressos nesse sentido. Nós não almejamos nenhuma autodeterminação, se é isso que o Sr. Césaire tinha em mente quando ele fez a comparação. Eu quero saber exatamente o que ele tinha em mente. ${ }^{54}$

Davis descreditou a apresentação de Césaire ao atentar para o fato de que a comunidade negra estadunidense e sua luta contra as leis de segregação se inseriam em uma dinâmica nacional específica. Essa população lutava, acima de tudo, segundo o antigo editor de The Crisis, para ser reconhecida como integrante legítima da nação da qual fazia parte, e essa frente de batalha não deveria ser confundida com um movimento que envolvesse reivindicações por autodeterminação. Era visível que a delegação estadunidense não se via contemplada pelas assertivas acerca de uma unidade cultural negra transcontinental nos termos apresentados até então, e que sua participação no evento havia sido acordada com a garantia de que assuntos delicados, como o anticolonialismo combatente de Aimé Césaire, não seriam o cerne dos debates.

54 “Débats”, pp. 214-215. 
O incômodo dos estadunidenses permeou os dois primeiros dias de debate e a tensão se instalou no auditório Descartes. A percepção das dificuldades que a aparentemente simples afirmação de um fundo cultural “negro-africano" teria trazido ao Primeiro Congresso, assim como o temor pelo rompimento prematuro das redes que se procurava fundar, aparece em um exemplo emblemático, no texto de George Lamming. O autor, nascido na ilha de Barbados, no Caribe, apresentou sua contribuição no dia 21 de setembro, dia seguinte ao debate detalhado acima, e concentrou-se na premissa de que "assim como o silêncio é a única linguagem universal, eu penso que se pode dizer que a política é a única base para uma simpatia Negra universal". ${ }^{55}$ Segundo Lamming, era preciso admitir que o que unia aqueles escritores e artistas no Primeiro Congresso era sua situação precária no interior de um mundo em que eles eram sempre marcados pela palavra "negro”. Essa especificidade não decorria do compartilhamento de um mesmo fundo cultural, mas de um inimigo em comum: o discurso ocidental de desqualificação do negro como o outro, oposto de sua autorrepresentação enquanto civilização:

O Negro é um homem que o Outro olha como Negro; e a dicotomia, a divisão, em si, que deve existir bem no centro dessa consciência, foi criada por esse velho e, ao que parece, eterno conflito entre a nomeação de uma coisa e o entendimento desta coisa. ${ }^{56}$

Lamming preocupava-se com a impossibilidade de mapear um compartilhamento cultural transcontinental, o que impediria a formação de alianças políticas entre comunidades negras em luta. Os organizadores do evento também temiam rupturas e um resultado que poderia ser lido como fracasso diante da imprensa e em solo ocidental. Os conflitos eram fonte de incertezas quanto à conclusão do Primeiro Congresso e, no terceiro dia, Alioune

55 George Lamming, “The Negro Writer and His World”, Présence Africaine, n. 8-9-10 (1956), p. 320.

56 Lamming, “The Negro Writer and His World”, p. 321. 
Diop iniciou as apresentações “afirmando que cada orador falava apenas por si mesmo e não podia ser considerado como se falasse pela totalidade da conferência”. ${ }^{57}$ Além disso, não houve debate após as apresentações.

Ao se manifestar de forma mais longa, como último palestrante do Primeiro Congresso, Wright reiterou o estranhamento dos delegados dos EUA diante das comunicações e demonstrou como o papel que a delegação estadunidense acreditava ter no evento divergia da posição de um grupo social subalterno ao Ocidente, como afirmara Césaire. Antes de iniciar sua apresentação, que segundo ele havia se modificado diante das sessões anteriores, Wright fez uma explanação do que seria o seu "clima mental”, o seu lugar social e o período histórico em que se encontrava, o que serviria para situar e qualificar sua comunicação: "Eu sou negro. Eu sou um homem do Ocidente. Esses dois fatos centrais condicionam, em certa medida, meu ponto de vista. Eu vejo e entendo o Ocidente; mas eu também vejo e entendo a perspectiva não ou antiocidental". ${ }^{58}$ Segundo ele, explicitar e admitir esses elementos que influenciavam seu modo de pensar seria a única forma de alcançar alguma objetividade. Essa explanação era já uma resposta às questões surgidas em torno da inserção da comunidade negra estadunidense em um conjunto transnacional negro-africano, como alguns intelectuais de expressão francesa tentaram afirmar nos dias anteriores.

Para Wright, apesar de entender o ponto de vista contrário, sua “ocidentalidade” deveria ser reiterada. Segundo o autor, a decorrência central desse lugar social era que ele sabia conceber a diferença entre o racional e o irracional e acreditava na necessidade de separar o mundo religioso do mundo secular.

O conteúdo da minha ocidentalidade reside, fundamentalmente, eu sinto, na minha perspectiva secular com relação à vida. Eu acredito na separação entre a Igreja e o Estado. [...] brevemente, eu acredito

57 Baldwin, "Princes and Powers", p. 57.

58 Richard Wright, "Tradition and Industrialization: The Plight of the Tragic Elite in Africa”, Présence Africaine, n. 8-9-10 (1956), p. 349. 
que o homem, para o bem ou para o mal, é seu próprio governante, sua própria soberania. Eu sustento que a liberdade humana é o direito e o bem supremo para todos os homens. ${ }^{59}$

E, devido a essa forma de entender o mundo, Wright, enquanto um homem ocidental, estava confuso com o fato de os intelectuais então presentes não considerarem que o colonialismo foi em parte bem-sucedido. Afinal, a dominação europeia teria tido o "mérito" de "libertar" os africanos de um mundo de irracionalismo:

Hoje, um homem negro, marrom ou amarelo consciente pode dizer: “Obrigada, Senhor Branco, por me libertar da decadência das minhas tradições e costumes irracionais, apesar de vocês permanecerem vítimas de seus próprios costumes e tradições irracionais! [...]” O mundo ocidental branco, até pouco tempo atrás a parte mais secular do mundo - uma secularidade que era o segredo de seu poder (ciência e indústria) - trabalhou inconsciente e tenazmente por 500 anos para transformar a Ásia e a África (isto é, a elite nessas áreas) em mais secular que o Ocidente. ${ }^{60}$

As apresentações que ele havia presenciado, em contrapartida, o deixavam, segundo seu texto, com dúvidas sobre a eficácia dessa libertação. Segundo Wright, o problema não estava no colonialismo em si, mas na maneira como ele foi levado a cabo pelos europeus. Se não fosse pelos erros cometidos na aplicação, a Europa poderia dizer orgulhosa e com razão: “'Olhe o que conseguimos realizar! Nós refizemos o homem a nossa imagem! Olhe para as novas formas de vida que nós trouxemos à vida!" 61 O que a elite africana reunida no Primeiro Congresso deveria se empenhar em garantir, portanto, era a concretização desse processo

59 Wright, “Tradition and Industrialization”, p. 350.

60 Wright, “Tradition and Industrialization”, p. 356.

61 Wright, “Tradition and Industrialization”, p. 357. 
começado pela colonização. Para isso, o Ocidente deveria permitir que essas pessoas usassem todos os meios necessários. Era como membro de uma delegação ocidental em um evento do Terceiro Mundo que Wright encerrava sua comunicação: “O problema é liberdade. Como os asiáticos e africanos podem ser livres de seus absurdos costumes e tradições e tornarem-se industrializados, e poderosos, pode-se dizer, como o Ocidente...?"62 Para Wright, portanto, a comunidade negra estadunidense deveria se comprometer diante das sociedades africanas em auxiliar materialmente na libertação, que caminharia ao lado da ocidentalização de sua cultura e não necessariamente da luta anticolonial.

Era o fim das apresentações e muitos impasses permaneciam. O discurso proferido por Richard Wright só confirmava a distância entre as colocações feitas por Alioune Diop no início do Primeiro Congresso de Escritores e Artistas Negros e os debates travados ao longo de seu desenvolvimento. As posições apresentadas pela delegação estadunidense e por Wright nos dias de apresentações e debates em Paris são sugestivas por apontar os limites que encontravam, nos anos estudados, as mobilizações baseadas em solidariedades internacionais fora de tutelas imperialistas. As lógicas assimétricas da organização do poder no cenário internacional não deixaram de existir e, apesar de reconfiguradas, permaneciam como obstáculos, por vezes intransponíveis, tanto para o internacionalismo, em ocasiões como a de Bandung, quanto para as articulações intelectuais que orbitaram a Présence Africaine e suas iniciativas e políticas culturais.

Além disso, havia, de certa forma, uma disputa pelo lugar de protagonismo no interior da intelectualidade presente no auditório Descartes. As diferentes demandas entre estadunidenses, caribenhos e oeste-africanos delineadas demonstravam que, partindo de prerrogativas políticas, sociais e culturais distintas, os participantes das discussões procuraram ocupar o papel de quem enunciaria as regras das alianças a serem construídas. Não por acaso, a recusa por parte de caribenhos e oeste-africanos em

62 Wright, “Tradition and Industrialization”, p. 358. 
celebrar a presença estadunidense como fator definidor de pautas e agendas a serem concretizadas figurou como uma quebra de expectativas grande para os intelectuais que então se manifestaram em nome da delegação dos EUA. Nesse sentido, a apresentação de Wright serviu como atestado da frustração do papel que esses intelectuais entendiam ocupar, enquanto guias políticos e culturais, fomentando economicamente projetos que se adequassem a uma ideia de libertação restrita aos termos do capitalismo e da democracia estadunidenses. A violência da argumentação do autor, defendendo de maneira mais ou menos explícita a ideia de colonialismo cultural diante de expoentes da Négritude e sua conhecida crítica ao conceito de "assimilação", aliada à afirmação inicial de Wright de que o tom do texto havia sido mudado devido aos dias anteriores de debate, mostram que havia um fosso entre as intenções estadunidenses então representadas e outros projetos internacionalistas que transitavam no Primeiro Congresso. Esses “delegados” não pretendiam ser inseridos no “espírito de Bandung”.

\section{A resolução final: a negociação das disputas}

Ao ler os debates reproduzidos nas atas, nota-se que a formação de uma rede intelectual em torno de uma única agenda gerou pontos de atrito que remetiam ao cenário internacional, tanto regional quanto global, mencionado no início deste artigo. Diferentes pontos de partida sociais, políticos, ideológicos e nacionais levaram a posicionamentos diversos. Questionamentos sobre conceitos de fundo para a própria justificativa da realização do evento em 1956 foram reiteradamente apresentados, apesar das tentativas da organização de esclarecê-los desde a primeira hora. Apesar disso, as discussões ganharam implicações interessantes por estarem inseridas em uma dinâmica de forças local na qual os lugares de decisão e organização eram ocupados por atores caribenhos e oeste-africanos. Foram esses últimos os que agiram no dia que se seguiu às comunicações para a continuidade dos planos de formação de uma aliança intelectual negra internacional. 
No último dia do Primeiro Congresso de Escritores e Artistas Negros, sábado, dia 22 de setembro de 1956, muito havia sido colocado em debate, mas pouco fora decidido. A situação colonial de alguns dos territórios representados e a localização do congresso, na capital da França, posicionavam o grupo sob vigilância direta da mídia e do poder político metropolitano. A delegação estadunidense, por sua vez, parecia poder deixar o auditório a qualquer momento, o que também funcionava como um direcionamento e, de certa forma, como uma restrição para os trabalhos. ${ }^{63}$

Como a declaração de pontos de vista políticos estava proibida, o debate "cultural” que se alastrou pelo auditório naquela manhã estava em perpétuo perigo de se afogar no mar do não declarado. Pois, de acordo com sua posição política, cada delegado possuía uma interpretação diferente de sua cultura, e uma ideia diferente sobre seu futuro, assim como dos meios a serem utilizados para tornar esse futuro realidade. [...] Então, levantou-se a questão de como o comitê deveria ser selecionado, se por países, ou por áreas culturais. Foi decidido, por fim, que o comitê deveria ser organizado de acordo com as áreas e deveria entregar suas resoluções ao meio-dia. ${ }^{64}$

A organização do evento demonstraria, porém, sua resolução em manter o andamento da programação e em negociar as divergências sem tomar decisões que excluíssem de forma abrupta os envolvidos nas contendas, mas mantendo pontos delicados no centro das atenções.

Como apontou Baldwin, estava previsto que o evento fosse finalizado após a criação de um comunicado final que representasse as delegações presentes e projetasse uma resolução sobre as culturas negras, sua situação de subalternidade e colonialismo na modernidade e uma agenda para retirá-las desse lugar - uma conclusão a partir das temáticas centrais tratadas durante o congresso. $\mathrm{O}$ documento foi finalizado no

63 Baldwin, "Princes and Powers”, p. 59.

64 Baldwin, “Princes and Powers”, p. 59. 
final da tarde do dia 22, extrapolando em algumas horas a projeção feita por Alioune Diop para o meio-dia, o que se deveu, em parte, ao impasse em decidir sobre como uma comissão para sua redação deveria ser selecionada. As conversas e possíveis negociações que foram feitas para sua escrita não se encontram transcritas nas atas publicadas pela Présence Africaine e foram feitas a portas fechadas, fora do alcance da caneta de James Baldwin. O pequeno texto final que foi lido ao público no auditório Descartes, porém, está publicado no número especial 8-9-10, em versão bilingue, em francês e em inglês.

Fundamentada em uma abordagem cultural em conjunto das populações ditas "negras” no mundo Ocidental e suas bordas, a resolução convidava "artistas, escritores, teólogos, pensadores, acadêmicos e técnicos para participar desta tarefa histórica de fazer reviver, de reabilitar e de desenvolver essas culturas a fim de favorecer sua integração ao todo da cultura humana”. ${ }^{65}$ A esse chamado, se seguia uma listagem das medidas a serem tomadas em nome da tarefa central de "reabilitação" e de "integração" das culturas negras. O ponto central era o fim do colonialismo e do racismo e o investimento intelectual em uma revitalização da "verdade histórica” sobre as riquezas dessas culturas.

A forma como o texto foi escrito, reunindo e aglomerando como sinônimos as diversas classificações que apareceram durante os debates ao longo do evento é uma pista de como as discordâncias foram contornadas ou minimizadas. A partir dessa estratégia, a diversidade interna ao grupo de delegados e culturas identificadas como "negras", aspecto em disputa durante as reações à apresentação de Léopold Sédar Senghor, surgia como paratexto:

Nós, escritores, artistas e intelectuais nègres, diversos em nossas ideologias políticas e em nossas confissões religiosas, provamos a necessidade de nos reunir nesta etapa crucial da evolução humana

65 “Résolution Finale”, Présence Africaine, n. 8-9-10 (1956), p. 362. 
para confrontar de uma maneira objetiva nossos pontos de vista sobre a cultura e os estudar, como homens conscientes de nossas responsabilidades diante de nossos respectivos povos, diante dos povos coloniais e semicoloniais e diante de todos os homens livres de boa vontade. ${ }^{66}$

O racismo e o colonialismo eram destacados, em conjunto, como causas das “condições sociais e gerais” que afetariam as “culturas negras”, o que remetia à comunicação de Aimé Césaire. A resolução final, portanto, ecoava as palavras e refletia o sucesso do discurso do martinicano ao afirmar que somente a destruição do racismo, do colonialismo e da exploração entre países promoveria o florescimento da cultura, o que denota uma escolha no âmbito regional africano pela bandeira da autodeterminação. No entanto, a definição exata do que era chamado de "culturas negras" foi evitada e optou-se por listar as diferentes e conflitantes proposições feitas durante o evento como se representassem aspectos complementares de um mesmo conceito, apresentando uma indisposição em reforçar as linhas de discordância atlânticas com o grupo estadunidense. Assim, parágrafos semelhantes se seguem:

Nosso Congresso convoca os intelectuais negros e todos os homens apaixonados pela justiça a lutar pela criação de condições concretas para o renascimento e para o florescimento das culturas nègres.

Nosso Congresso, que presta homenagem às culturas de todos os países e aprecia sua contribuição ao progresso da civilização, convoca todos os intelectuais negros a defender, a ilustrar e a tornar conhecidos em todo o mundo os valores nacionais de seus povos. ${ }^{67}$

Essa configuração do comunicado final aponta para a tendência de internacionalização temática e de alianças que marca a Présence Africaine

66 "Résolution Finale", p. 362.

67 “Résolution Finale”, p. 362. 
no final da década de 1950 e durante os anos 1960, com destaque para a parceria com atores estadunidenses. Amplia-se a área de interesse e o espaço ideal de alcance da revista, que vislumbra a possibilidade de falar a um "mundo negro”, a partir da África do Oeste presente em Paris, e de aplicar no futuro africano os benefícios dos contatos mundiais. Nesse aspecto, o periódico apropriava-se do discurso terceiro-mundista em conjugação com os aspectos transcontinentais do pan-africanismo e da Négritude, sem abdicar de ligações com lideranças estadunidenses liberais e nacionalistas. Aqui vale lembrar da reiterada autoproclamação da Présence Africaine como apartidária e distante de qualquer “domesticação” ideológica ou política.

O modelo da política internacional e o exemplo de Bandung se fizeram visíveis com a reprodução da linguagem e teor da Carta das Nações Unidas, de 1945, na resolução final, em 1956: "Nosso Congresso convida todos os intelectuais negros a unir seus esforços para que se torne efetivo o respeito aos direitos do homem - seja qual for sua cor - dos povos e das nações - independentemente de quais sejam elas". ${ }^{68} \mathrm{O}$ uso da Declaração de Direitos do Homem e da autodeterminação dos povos demonstrava alguma familiaridade com o discurso do direito internacional e uma tomada de posse de sua divisão do mundo em nações, mas de forma parcial.

A vivência do evento de 1955, ao qual compareceram, por exemplo, Alioune Diop e Richard Wright, havia provado a possibilidade de diálogo e alianças frutíferas em termos nacionais e foi, portanto, destacada como um modelo para o Primeiro Congresso de Escritores e Artistas Negros, em 1956. Como resultado, a solidariedade proposta conjugava a linguagem, o modelo e a experiência de Bandung com elementos vindos de outros contextos, principalmente da identificação racial embasada pelo pan-africanismo e a Négritude. Tanto a dimensão racial do engajamento pan-africanista ou negritudiano quanto a presença de atores coletivos de variados espectros políticos eram escolhas que visavam

68 “Résolution Finale”, p. 362. 
à institucionalização das redes em gestação do Primeiro Congresso e à criação de um canal direto de intervenção no mundo social.

Sugestivamente, no mesmo dia de finalização do encontro em Paris, um anúncio foi feito: "por demanda de vários congressistas, a diretoria aceita a missão de criar uma Associação Internacional dos Homens de Cultura Negros" ${ }^{69}$ Essa instituição seria intitulada Société Africaine de Culture (SAC). Ao longo da década de 1960, com o aumento de países independentes e com a mudança de cenário político no continente africano, a SAC emergiria como um organismo autônomo, capaz de articular diferentes interesses e pleitear alianças nacionais sem se ligar diretamente, de forma definitiva, a nenhum país. Não por acaso, a sede da instituição, assim como da redação da Présence Africaine, permaneceu em Paris, mesmo após a separação política oficial entre a França e a antiga AOF, provavelmente uma escolha ligada à visibilidade internacional e à facilidade logística e, ao mesmo tempo, à manutenção do legado, do discurso e de práticas transnacionais. Com o crescimento da importância da SAC, que se torna organização não governamental associada à ONU em 1958, aumentam as possibilidades de negociação e atuação da Présence Africaine na organização de eventos multinacionais e no fomento de caminhos para políticas culturais nacionais e regionais.

\section{Considerações finais}

Vê-se que, na década de 1950, a ideia de uma unidade racial foi perturbada por outros pertencimentos, e o modelo de ação do intelectual negro lidou com novas disputas no interior da Présence Africaine. Com as independências na Ásia e a inserção de fenômenos semelhantes no horizonte de expectativas dos territórios oeste-africanos, a participação em um novo movimento de alianças forjadas pelo pertencimento a uma condição histórica de subalternidade política se tornou uma possibilidade

69 “Résolution Finale”, p. 362. 
que não foi descartada. Do ponto de vista da Présence Africaine e da intelectualidade em seu entorno, Bandung fortaleceu uma chance de aliança externa à identidade racial ou colonial, mas isso não foi visto como uma via exclusiva, mas como palco complementar.

De forma regional, o periódico foi criado e estava em constante troca com elites africanas que negociavam, durante as décadas de 1950 e de 1960, projetos de governo para um continente africano posterior ao colonialismo. Assim como no Primeiro Congresso de Escritores e Artistas Negros, o momento era de intensa disputa, com grande diversidade de atores coletivos e individuais, bem como de intervenções e lugares sociais. Interesses diferentes se encontravam em conflito. Em meados da década de 1950, como se viu até aqui, o colonialismo surge como um regime político a ser combatido, mas as ideias de liberdade política e autonomia cultural não eram encaradas como sinônimos naturais de independência por todos. O período entre 1956 e 1960 foi palco de intensas mudanças e decisões jurídicas e institucionais na relação entre as antigas colônias africanas e a Europa, e ao mesmo tempo de imaginação de futuros nacionais, federativos, multinacionais ou até transcontinentais.

Todos esses elementos políticos regionais eram também tensionados por configurações que trouxeram para o evento de 1956 vários dos pontos que delimitavam as disputas políticas em um âmbito global, nos primeiros anos de Guerra Fria. Foi assim que a delegação estadunidense se tornou o epicentro de polêmicas e divergências que ameaçaram a continuidade dos trabalhos.

Enquanto um congresso desenvolvido fora do âmbito oficial das relações internacionais, promovido e povoado por agentes identificados como "escritores e artistas" e com temática manifestamente "cultural”, o Primeiro Congresso de Escritores e Artistas Negros nem sempre é pensado a partir de suas implicações para a projeção de alianças que fomentaram embates e debateram conceitos centrais para entender configurações políticas globais. A natureza dos registros trabalhados neste artigo mostra, porém, uma possibilidade de traçar 
agências históricas externas ao mundo bipolar. Um repertório de práticas e significados gestados em ocasiões oficiais das disputas pela formação de uma nova ordem mundial passa a extrapolá-las, fazendo sentido na imbricação entre contextos locais e projetos globais mesmo em campos como o intelectual.

A criação e o fortalecimento de um “mundo negro” emergem como bandeiras duradouras da Présence Africaine, mas sem evitar que ela dialogue, negocie e se aproprie da responsabilidade de pensar a África e suas identidades em solo africano e defender a necessidade de Estados fortes, de planificações nacionais e da “africanização” do intelectual africano e suas práticas. Em um ambiente político no qual projetos distintos e até conflitantes emergem, a existência da revista se basearia em alianças tanto pela mobilização de identidades regionais quanto de imagens mais amplas, como a do "terceiro mundo”. Da mesma forma que pensar o futuro para o continente africano era uma pauta da qual a revista não se privaria, assim o eram o antirracismo e o anticolonialismo. No contexto aqui debatido, isso significou o investimento na prática do encontro, assim como a confiança no crescimento da relevância de alianças internacionais que se fundamentavam ora pelo conceito de Terceiro Mundo, ora pela identidade racial.

Por fim, o Primeiro Congresso é uma forte advertência para a dimensão política que a conceituação de pontos como cultura, raça e identidade poderia ter em um evento que promoveu a ideia da criação de uma unidade intelectual negra internacional com agenda unificada nos idos dos anos 1950. A própria ideia de que era impossível e indesejável a separação total entre o trabalho intelectual e o engajamento em questões políticas e sociais de interesse imediato foi longamente defendida em várias ocasiões pela Présence Africaine antes e depois do período trabalhado, ${ }^{70}$ além de figurar como um elemento central do campo intelectual francês, ${ }^{71}$

70 Reis, “África imaginada”, pp. 152-165.

71 Jean-Paul Sartre, Que é a literatura?, São Paulo: Editora Ática, 2004. 
com o qual a revista travou constante conversação. ${ }^{72}$ Isso leva à conclusão de que os desdobramentos das pautas propostas para as discussões em 1956 eram previsíveis, mesmo para os participantes estadunidenses, e que sua indignação diante da “cultura como pretexto” era uma crítica não à dimensão política do evento em si, mas aos caminhos que essa política tomava, guiada por ideias de ruptura. A opção pela fuga de temáticas explícitas não esvaziou os embates políticos que extrapolavam o evento e que também ajudaram a moldá-lo, nem impediu que as relações entre liberdade política e cultural, ou colonialismo e racismo, fossem levantadas e suscitassem embates que quase comprometeram a sua continuidade, colocando em destaque o protagonismo de atores americanos e oeste-africanos.

Recebido em 22 jun. 2020

Aprovado em 26 ago. 2020

doi: 10.9771/aa.v0i62.37460

72 Bennetta Jules-Rosette, “Jean-Paul Sartre and the Philosophy of Négritude: Race, Self, and Society”, Theory and Society, n 36 (2007), pp. 265-285. 
Este artigo parte das publicações da revista cultural francesa e senegalesa, Présence Africaine, propondo pensar como esta última procurou se posicionar, partindo do mundo intelectual, como interventora na imaginação e no fomento de soluções políticas e culturais para inserir novos participantes, principalmente africanos, no concerto internacional, em diálogo com bandeiras de solidariedade internacional/racial entre perspectivas locais e globais. Por meio da análise de debates, comunicações e mensagens retiradas das atas do Primeiro Congresso de Escritores e Artistas Negros, investiga-se como a revista se apropriou de novas linguagens e possibilidades políticas disponíveis e legitimadas no pós-Segunda Guerra Mundial, conciliando-as, não sem dificuldades, a discursos internacionalistas de movimentos políticos anteriores, como a Négritude e o pan-africanismo.

Présence Africaine | Negritude | Pan-africanismo | História intelectual | Guerra Fria

\section{Between Culture, International Solidarity and the “Black World": The Negotiation of Meaning in Présence Africaine (1955-1956)}

This paper is based on publications of the French/Senegalese journal Présence Africaine and its intellectual stance in seeking to intervene in the design and dissemination of political/cultural solutions to include new participants (especially from Africa) in the international scene, in dialogue with the goal of international/racial solidarity goals at local and global levels. The paper examines debates, communications and messages from the annals of the First Congress of Black Writers and Artists in investigating how the journal appropriated new communicative strategies and political possibilities that emerged and were legitimized after World War II, in relation to the internationalizing discourses of previous political movements such as Négritude and Pan-Africanism.

Présence Africaine | Négritude | Pan-Africanism | Intellectual history | Cold War 